\title{
Baicalin inhibits Escherichia coli isolates in bovine mastitic milk and reduces antimicrobial resistance
}

\author{
Q. Y. Zhao, F. W. Yuan, T. Liang, X. C. Liang, Y. R. Luo, M. Jiang, S. Z. Qing, ${ }^{1}$ and W. M. Zhang ${ }^{1}$ \\ College of Veterinary Medicine, Northwest A\&F University, Yangling 712100, Shaanxi, China
}

\section{ABSTRACT}

In this study, we aimed to evaluate the inhibitory effect of baicalin on Escherichia coli in vitro and the effects of baicalin treatment on antimicrobial resistance of the E. coli isolates. Through isolation, purification, and identification, a total of $56 \mathrm{E}$. coli strains were isolated from 341 mastitic milk samples. The study of inhibition effect of baicalin on the E. coli strains in vitro was focused on permeability and morphology of the isolates using an alkaline phosphatase kit and scanning electron microscopy. Furthermore, the resistance spectrum of the isolates to the common antimicrobial agents was tested at sub-minimum inhibitory concentrations of baicalin by the agar dilution method. Extendedspectrum $\beta$-lactamase and plasmid-mediated quinolone resistance genes were amplified by PCR before and after incubation with baicalin. The results revealed that baicalin has certain inhibitory effects on the isolates in vitro. The alkaline phosphatase enzyme activity was significantly increased from 1.246 to $2.377 \mathrm{U} / 100 \mathrm{~mL}$, and the surface of $E$. coli was concave and shriveled. Analysis of the resistance spectrum and PCR amplification showed that, after administration with baicalin, the sensitivity of most strains to the selected antimicrobial agents was enhanced. Strikingly, the drug-resistant genes from $71.43 \%$ (40/56) of these isolates were found to have drug-resistant genes to different extents. Altogether, the current study confirmed both the inhibitory effect on Escherichia coli in vitro and the reduction of antimicrobial resistance by baicalin. This is the first comprehensive study to report on baicalin, a traditional Chinese medicine that acts on $E$. coli isolated from the mastitic milk samples.

Key words: baicalin, Escherichia coli, multi-drug resistance, bovine mastitis

Received June 19, 2017.

Accepted October 11, 2017.

${ }^{1}$ Corresponding authors: suzhuqing@163.com and ylzhangwm@163. com

\section{INTRODUCTION}

Bovine mastitis, inflammation of the mammary gland, is a damaging and costly disease facing dairy farmers throughout the world (Halasa et al., 2007; Heikkilä et al., 2012). Due to the large-scale adoption of the 5-point plan, mastitis has been successfully controlled in many countries for decades (Neave et al., 1969; Hillerton et al., 1995; Zadoks et al., 2002), although the incidence of pathogens, such as Escherichia coli (Olde Riekerink et al., 2010), Staphylococcus aureus (Olde Riekerink et al., 2008), and Streptococcus uberis (Levison et al., 2016), is still prevalent on many farms. As a major pathogen causing environmental mastitis, $E$. coli is difficult to be cured because of its ubiquitous existence, easy transmission, and rapidly emerging drug resistance properties (Olde Riekerink et al., 2010; Steeneveld et al., 2011; Saini et al., 2012; Dahmen et al., 2013).

For successful implementation of a clinical E. coli mastitis control program, it is important to identify the pathogen. This microbiological analysis can be done through isolation and identification of pathogenic bacteria from infected cows. Antimicrobial agents are used for therapeutic as well as preventive measures against bacterial infections including bovine mastitis in farm animals (Lindeman et al., 2013). Unfortunately, several recent studies have reported the increasing occurrence of highly multi-drug-resistant $E$. coli isolated from food-producing animals from various countries including China (Rao et al., 2014; Xu et al., 2015; Seni et al., 2016). Therefore, the need for a safe, novel, costeffective, alternative therapeutic strategy, especially of herbal origin, is extremely urgent. Susceptibility of bacteria to antimicrobial agents decreases with increasing resistance. Because mechanisms of bacterial resistance are numerous and intractable, reducing or eliminating antimicrobial resistance is challenging.

Traditional Chinese medicines have long been used to treat a wide range of pathologies, and research about their mechanisms of pharmacological activity is very extensive. Some reports have shown that Scutellaria baicalensis, one of the most popular and multi-purpose herbs, has strong antimicrobial effects in vitro. Related 
research has reported that $S$. baicalensis contains numerous flavonoids, such as baicalin, baicalein, wogonin, and chrysin ( $\mathrm{Li}$ and Chen, 2005). Some of these flavonoids such as baicalin have been demonstrated to have antioxidant (Chan et al., 2008), antibacterial (Huang, 1999), antiviral (Huang et al., 2000), and antiinflammatory activities (Huang et al., 2006). In addition to its multi-purpose pharmacological actions, baicalin's bacteriostatic mechanisms include destruction of bacterial cell membranes; inhibition of bacterial DNA, RNA, and protein biosynthesis; and degradation of endotoxins (Wu, 2011). However, no research has evaluated the effects of baicalin on E. coli isolated from mastitic milks. Therefore, in the present study, we isolated E. coli from mastitic milk samples and investigated the antibacterial activity of baicalin against $E$. coli in vitro and its effect on drug resistance.

\section{MATERIALS AND METHODS}

\section{Materials}

Baicalin (purity >95\%) was purchased from the National Institute for the Control of Pharmaceutical and Biological Products (Beijing, China). Antimicrobial pretreated paper discs and biochemistry reaction tubes were purchased from Hangzhou Tianhe Microorganism Reagent Co. Ltd. (China). Mueller-Hinton, MacConkey (MAC), eosin methylene blue agar, LuriaBertani (LB), and Mueller-Hinton broth medium were purchased from Beijing Aoboxing Bio-Tech Co. Ltd. (China). Taq DNA polymerase was purchased from Beijing Dingguo Changsheng Biotechonlogy Co. Ltd. (China). An alkaline phosphatase (AKP) kit was purchased from Nanjing Jiancheng Bioengineering Institute (China). All other chemicals were of reagent grade.

\section{Bacteriological Examination}

Milk samples of mastitic cows $(\mathrm{n}=341)$ were collected from 26 dairy herds located in 4 cities (Baoji, Weinan, Xi'an, and Yangling) of Shaanxi province of China. Milk samples were collected using procedures outlined by Rajala-Schultz et al. (2004). Briefly, dirt, bedding, and hair were brushed from teats using a dry paper towel. Teats were then dipped in $4 \%$ sodium hypochlorite. Germicide was allowed to contact teats for at least $30 \mathrm{~s}$ before being thoroughly dried with single-service paper towels. Teat ends were scrubbed with cotton balls moistened with $70 \%$ ethyl alcohol. The 10-mL milk samples collected from each mammary quarter at the front end were discarded. Five to 10 $\mathrm{mL}$ of milk from each mammary quarter was collected into a separate sterile polypropylene test tube. Samples were frozen and transported immediately to the laboratory for microbiological culture.

The milk samples were inoculated in LB broth and incubated for 12 to $18 \mathrm{~h}$ at $37^{\circ} \mathrm{C}$. Then, the incubated samples were streaked on a MAC plate for 18 to $24 \mathrm{~h}$ at $37^{\circ} \mathrm{C}$. With a sterile loop, 1 or 2 pink colonies from the MAC plate were picked up and streaked on the other MAC plate for 18 to $24 \mathrm{~h}$ at $37^{\circ} \mathrm{C}$. Further identification of $E$. coli was performed according to the methods described by the National Mastitis Council (Barnes Pallesen et al., 1987). Routine bacterial examination, such as colony morphology, Gram stain test, typical growth on eosin methylene blue agar (Hogan et al., 1999), and micro-biochemical reaction were performed. The specific $16 \mathrm{~S}$ rRNA sequence of $E$. coli was also analyzed by PCR (Zhu et al., 2007). The primer (forward: 5'-AAGAAGCTTGCTTCTTTGCTG-3'; reverse: 5'-GAGCCCGGGGATTTCACAT-3') was finally used to amplify the $16 \mathrm{~S}$ rRNA gene. The cycling conditions were an initial step of $5 \mathrm{~min}$ at $94^{\circ} \mathrm{C}, 35$ cycles of $30 \mathrm{~s}$ at $94^{\circ} \mathrm{C}, 40 \mathrm{~s}$ at $54^{\circ} \mathrm{C}$, and $1 \mathrm{~min}$ at $72^{\circ} \mathrm{C}$, followed by 10 min at $72^{\circ} \mathrm{C}$.

\section{Antibacterial Activity}

The MIC of baicalin against the test bacteria was determined by broth dilution according to a modified method of Bandyopadhyay et al. (2008). With a sterile loop, 4 to 5 colonies of $E$. coli were picked up and suspended in $3 \mathrm{~mL}$ of LB broth and adjusted to $1 \times 10^{4}$ $\mathrm{cfu} / \mathrm{mL}$ by dilution with LB broth. Fifty microliters of the bacteria suspension was added into each well of a sterile cell culture 96-well plate. Baicalin were diluted with LB broth to prepare a range of concentrations (1, $3,6,9$, and $12 \mathrm{mg} / \mathrm{mL}$ ); then, $100-\mu \mathrm{L}$ samples were added into each test well containing the bacteria. For the positive control, LB broth was added at $100 \mu \mathrm{L}$ in wells containing $50 \mu \mathrm{L}$ of bacteria. For the negative control, LB broth was added at $150 \mu \mathrm{L}$ in wells containing no bacteria. Finally, $15 \mu \mathrm{L}$ of resazurin $(1 \mathrm{mg} /$ $\mathrm{mL}$ ) was added into each well. Three parallels of the well were made in each group. The MIC was defined as the lowest concentration of the samples at which the microorganism did not demonstrate visible growth after $24 \mathrm{~h}$ of incubation at $37^{\circ} \mathrm{C}$. Microorganism growth was indicated by color change of the resazurin from blue to pink.

\section{Bacteria Cell Wall Permeability}

To examine the effect of baicalin on permeating of the E. coli cell wall, the methods of Zhou et al. (2016) 
and Yap et al. (2015) were adapted. The MIC of baicalin was $4 \mathrm{mg} / \mathrm{mL}$, and concentration of baicalin used in this trial was sub-MIC $(1 / 2 \mathrm{MIC}, 2 \mathrm{mg} / \mathrm{mL})$. In the experimental group, $100 \mu \mathrm{L}$ of bacterial suspension (1 $\times 10^{4} \mathrm{cfu} / \mathrm{mL}$ ) was inoculated into $10 \mathrm{~mL}$ of $\mathrm{LB}$ broth containing baicalin $(2 \mathrm{mg} / \mathrm{mL})$. The negative and positive control groups had $100 \mu \mathrm{L}$ of adjusted suspension $\left(1 \times 10^{4} \mathrm{cfu} / \mathrm{mL}\right)$ or baicalin $(2 \mathrm{mg} / \mathrm{mL})$, respectively. Three parallels were made in each group. Then the treated mediums were incubated at $37^{\circ} \mathrm{C}$ with agitation at $200 \mathrm{rpm}$. Bacterial cell wall permeability was determined at intervals of $0,2,4,6$, and $8 \mathrm{~h}$ using the AKP kit according to the instructions for E. coli.

\section{Scanning Electron Microscopy Screening}

In the bacteria cell wall permeability experiment, 5 $\mathrm{mL}$ of inoculum with a period of $8 \mathrm{~h}$ of incubation was subjected to scanning electron microscopy (Ganderton et al., 1992). A sterile coverslip $(6 \mathrm{~mm} \times 6 \mathrm{~mm})$ was put into the inoculum and incubated at $37^{\circ} \mathrm{C}$ for $1 \mathrm{~h}$. Then the coverslip was clamped with sterile forceps lightly and dried under natural conditions. Sample fixation was carried out with $2.5 \%$ glutaraldehyde for $1 \mathrm{~h}$, and then stored at $4^{\circ} \mathrm{C}$ for $12 \mathrm{~h}$. The coverslip was washed with PBS (pH 7.4) 2 to 3 times. Sequential exposure to different concentrations of alcohol (30\% to 90\%) caused further dehydration of the samples. The samples were subsequently subjected to critical point drying, sputter-coated with gold, and observed under an scanning electron microscope (S-4800, Hiachi High-Technologies Corporation, Takeda Hitachinaka-City, Japan). Three parallels were made in each group sample.

\section{Antimicrobial Susceptibility Testing}

The MIC of antimicrobial agents to the isolates in vitro were determined by an agar dilution method according to the standards described by the Clinical and Laboratory Standards Institution (M100-S25 and VET01-A4/VET01-S2). Concentration of the bacterial suspension was $1 \times 10^{4} \mathrm{cfu} / \mathrm{mL}$, and concentration of baicalin used in this trial was sub-MIC $(2 \mathrm{mg} / \mathrm{mL})$. The following antimicrobials were assessed: ampicillin, penicillin, cefotaxime, cefoxitin, enrofloxacin, ciprofloxacin, ofloxacin, erythromycin, cillimycin, gentamicin, streptomycin, chloramphenicol, and tetracycline. Escherichia coli ATCC 25922 was used as the control strain.

Isolates were classified as either susceptible or resistant according to the interpretive criteria recommended by the Clinical and Laboratory Standards Institute (M100-S25; ampicillin, penicillin, cefotaxime, cefoxitin, ciprofloxacin, ofloxacin, erythromycin, cillimycin, and streptomycin), and veterinary Clinical and Laboratory
Standards Institute (gentamicin, enrofloxacin, tetracycline, and chloramphenicol) (VET01-S2). Escherichia coli ATCC strain 25922 was used as the quality control in the antimicrobial susceptibility testing. The experiment was performed in triplicate.

\section{Resistance DNA Extraction and Analysis}

Extraction of DNA was carried out using the boiling method according to the Dei-Tutuwa's instructions for E. coli (Dei-Tutuwa et al., 2014). Frequently detected and studied genes, the plasmid-mediated quinolone resistance (PMQR) genes [qnrA, qnrB, qnrC, $\left.q n r D, q n r S, q e p A, \operatorname{aac}\left(6^{\prime}\right)-I b-c r, o q x A, o q x B\right]$ and the extended-spectrum $\beta$-lactamases (ESBL; $b l a_{\text {CTX-M }}$, $\left.b l a_{\mathrm{TEM}}, b l a_{\mathrm{SHV}}, b l a_{\mathrm{OXA}}\right)$, were chosen to amplify. All the oligonucleotide primers were synthesized by Zhuang et al. (2012) and Wang et al. (2013). The controls of strains that contained these genes came from the Pharmacological Laboratory of Northwest Agricultural and Forestry University. Polymerase chain reactions were performed on $0.5 \mathrm{~mL}$ of DNA using Taq DNA polymerase and $1 \mathrm{mM}$ of each primer. All PCR products were analyzed by electrophoresis in $1 \%$ (wt/vol) agarose gel. Gels were then stained with ethidium bromide and photographed under UV light. All amplified samples were sequenced and compared with known sequences using the BLAST program at the National Center for Biotechnology Information website (http://www.ncbi .nlm.nih.gov/BLAST).

\section{RESULTS}

\section{Bacteriological Examination and Determination of MIC}

Through the isolation, purification, and identification of pathogenic bacteria, 56 strains of E. coli were obtained from the 341 milk samples from 341 cows (Table 1). The antibacterial activity of baicalin to the isolated $E$. coli strains did not show variability because the MIC of baicalin to the E. coli strains was $4,000 \mu \mathrm{g} /$ $\mathrm{mL}$ for all.

\section{Bacteria Cell Wall Permeability Assay}

The activity of AKP representing the permeability of cell walls was illustrated in Figure 1. With the prolonged culture period, the enzyme activity was significantly increased from 1.246 to $2.377 \mathrm{U} / 100 \mathrm{~mL}$. No significant changes were detected in either control group. This meant that AKP passed through the cell wall into the broth due to the effect of baicalin. 
Table 1. Escherichia coli isolated from dairy herds located in 4 cities of Shaanxi province of China

\begin{tabular}{llrr}
\hline City & No. of dairy herds ${ }^{1}$ & No. of milk samples $^{2}$ & Escherichia coli isolates $^{3}$ \\
\hline Baoji & BJ1/BJ2/BJ3/BJ4/BJ5/BJ6/BJ7 & $96(9 / 12 / 12 / 15 / 21 / 16 / 11)$ & $14(1 / 2 / 2 / 2 / 3 / 3 / 1)$ \\
Weinan & WN1/WN2/WN3/WN4/WN5/WN6/WN7 & $90(13 / 8 / 12 / 10 / 14 / 17 / 16)$ & $13(2 / 1 / 2 / 1 / 2 / 3 / 2)$ \\
Xi'an & XA1/XA2/XA3/XA4/XA5/XA6/XA7/XA8/XA9 & $114(19 / 14 / 9 / 17 / 15 / 7 / 9 / 11 / 13)$ & $22(3 / 2 / 2 / 3 / 3 / 1 / 3 / 2 / 3)$ \\
Yangling & YL1/YL2/YL3 & $41(15 / 12 / 14)$ & $7(3 / 2 / 2)$ \\
\hline
\end{tabular}

${ }^{1}$ The letters indicate the city of sampling. BJ = Baoji; WN = Weinan; XA = Xi'an; YL = Yangling. The numbers after the letters represent the number of dairy herds.

${ }^{2}$ The first number indicates the total, and the numbers in parentheses indicate the sampling numbers corresponding to the farms in the second column.

${ }^{3}$ The first number indicates the total, and the numbers in parentheses show the Escherichia coli isolate numbers from the respective farms.

\section{Scanning Electron Microscopy Screening}

Electron microscopy observations further illustrated morphological changes in E. coli after incubation with MIC of baicalin for $8 \mathrm{~h}$. Baicalin-untreated bacteria exhibited membrane structure integrity with a plump cell (Figure 2A). In contrast, the surface of E. coli showed depressions and damage following incubation with baicalin (Figure 2B), indicating that baicalin might attach and penetrate the cell membrane of bacteria, resulting in changes of membrane permeability.

\section{Susceptibility Test of the E. coli Isolates}

Resistance rates of the $56 \mathrm{E}$. coli isolates to the 13 antimicrobial agents before and after the baicalin

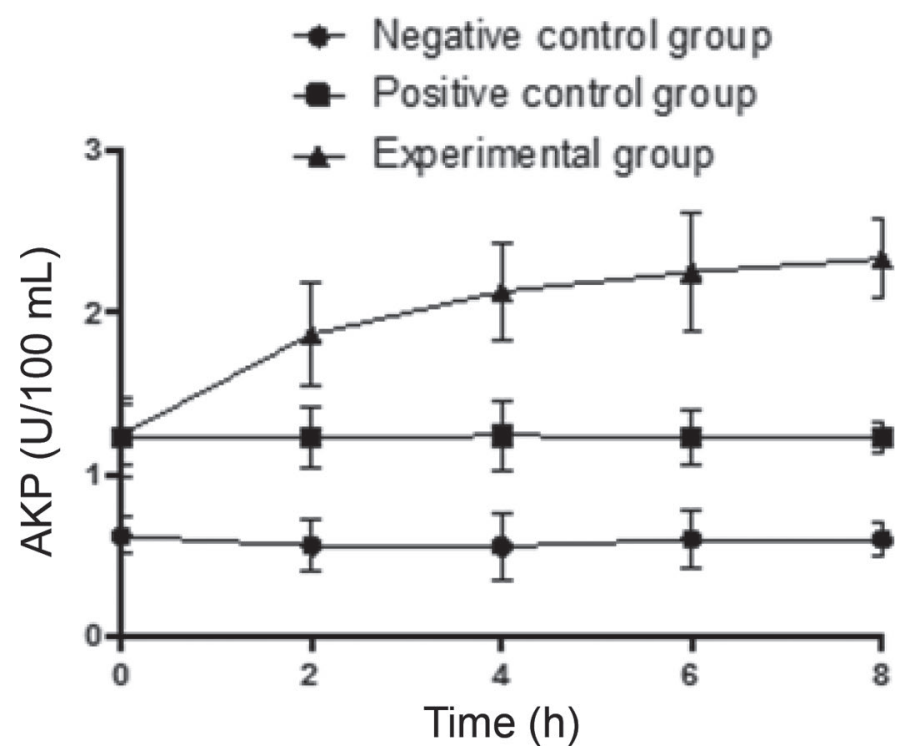

Figure 1. Effects of baicalin on the cell wall permeability of Escherichia coli. The concentration of baicalin was $2 \mathrm{mg} / \mathrm{mL}$, and the concentration of Escherichia coli was $1 \times 10^{2} \mathrm{cfu} / \mathrm{mL}$. AKP $=$ alkaline phosphatase. The error bars indicate the SD of each data set. incubation are shown in Table 2. Before the incubation, susceptibility testing showed that the resistance rates of the $\beta$-lactams to the isolates were 7.1 to $100 \%$. Penicillin and ampicillin, in particular, showed higher resistance rates. Only 4 isolates showed resistance to cefotaxime. The resistant strains of cefotaxime and cefoxitin were also resistant to penicillin and ampicillin. The resistance rates of the fluoroquinolones, enrofloxacin, ofloxacin, and ciprofloxacin, to the isolates ranged from 33.9 to $46.4 \%$. Seventeen of the isolates had co-resistance to all the 3 fluoroquinolones. Fifteen of the isolates had multi-resistance to penicillin, ampicillin, enrofloxacin, ofloxacin, and ciprofloxacin. A high proportion of resistance to other antimicrobial agents commonly used on animal farms was also demonstrated in this study, including erythromycin $(98.2 \%)$, cillimycin $(94.6 \%)$, and achromycin $(46.4 \%)$.

Under the interference of baicalin, the resistance rates of the $\beta$-lactams decreased from 1.7 to $14.3 \%$. The most significant reductions were streptomycin $(25.0 \%)$, ciprofloxacin (19.6\%), and ampicillin (14.3\%). Except for erythromycin and cillimycin, all of the antimicrobials had increased susceptibility to the isolates.

\section{Effects of Baicalin on the Drug-Resistance Genes of E. coli Isolates}

Overall, a total of $32(57.14 \%, 32 / 56) E$. coli isolates showed the presence of at least one ESBL gene and were included in the analysis (Table 3 ). $B l a_{\text {CTX-M }}$ was the most prevalent ESBL gene $(65.63 \% ; 21 / 32)$, whereas $b l a_{\mathrm{TEM}}$ and $b l a_{\mathrm{SHV}}$ genes were present in $56.25 \%(18 / 32)$ and $21.88 \%(7 / 32)$ of ESBL-positive isolates, respectively. $B l a_{\text {OXA }}$ was not detected. Eighteen (32.14\%) isolates were detected as PMQR genes producing $E$. coli. The data set comprised 6 different PMQR genes: oqxB $(38.89 \%, 7 / 18)$, oqxA $(33.33 \%, 6 / 18)$, aac $\left(6^{\prime}\right)-I b$ $\operatorname{cr}(22.22 \%, 4 / 18)$, qnrD $(22.22 \%, 4 / 18)$, qnrB $(16.67 \%$, $3 / 18)$, qnrS $(16.67 \%, 3 / 18 \%)$. oqxA were most frequently observed together with oqxB. $Q n r A, q n r C$, and qepA were not detected. 

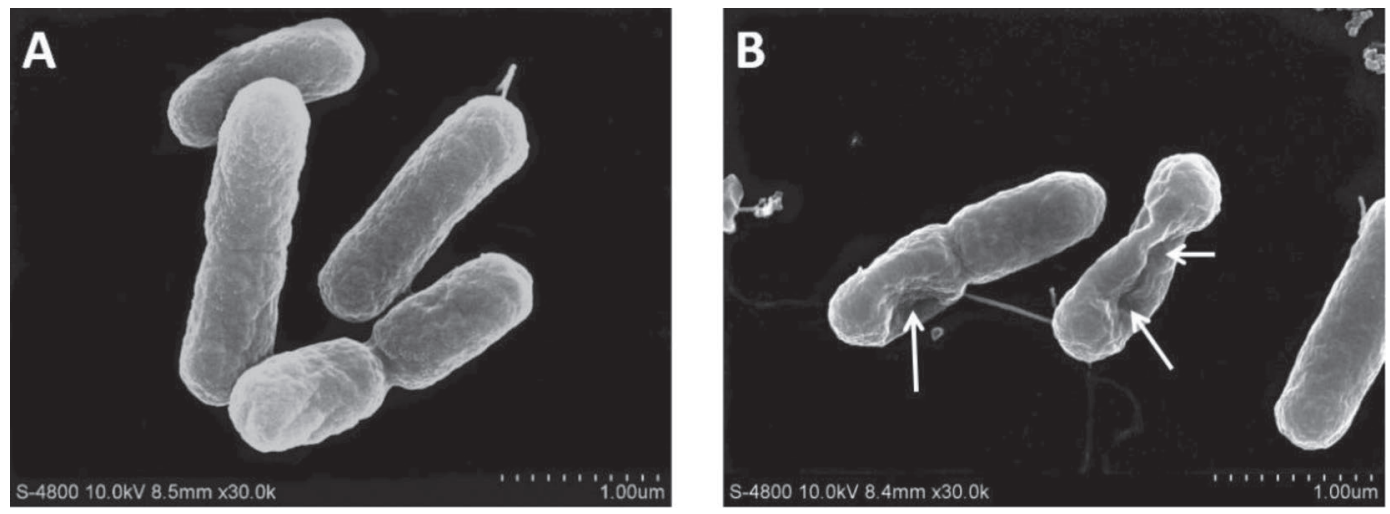

Figure 2. The morphological changes of Escherichia coli treated with baicalin. (A) The control group without the baicalin; (B) the experimental group treated with the baicalin. The concentration of baicalin was $2 \mathrm{mg} / \mathrm{mL}$, and the concentration of Escherichia coli was $1 \times 10^{2}$ cfu/ $\mathrm{mL}$ with a period of $8 \mathrm{~h}$ of incubation. The arrows indicate the depressions at the surface of $E$. coli.

Changes of drug resistance genes are presented in Figure 3. Many drug resistance genes were affected by baicalin. Among them, the loss of genes was as follows: qnrD $50 \%$ (2/4 isolates), oqxA $33.33 \%(2 / 6)$, qnrS $33.33 \%(1 / 3)$, bla $a_{\mathrm{SHV}} 28.57 \%(2 / 7), b l a_{\mathrm{TEM}} 22.22 \%$ $(4 / 18)$, oqxB $14.29 \%(1 / 7)$, and bla $a_{\text {СтХ-м }} 9.5 \%(2 / 21)$. No changes in the $q n r B$ and $a a c\left(6^{\prime}\right)-I b-c r$ resistance genes were observed.

\section{DISCUSSION}

Antimicrobial therapy is commonly used for prevention and control of mastitis. Unfortunately, treatment failure is common because of antimicrobial resistance (Metzger and Hogan, 2013). In this study, we evaluated antibacterial activity and mechanisms of baicalin in vitro on E. coli. Meanwhile, the possible effects on the prevalent drug resistance genes were investigated for the available medication mechanisms (Ali et al., 2016).
After a routine identification test, $56(16.42 \%) E$. coli strains were obtained from the 341 mastitic milk samples, which had higher occurrence compared with previous reports from China (Ali et al., 2016). Bacteriostatic test in vitro showed that the MIC of baicalin to $E$. coli strains was $4 \mathrm{mg} / \mathrm{mL}$, which indicated that baicalin had weak antibacterial activity against the $E$. coli strains. Similar research reported baicalin against antimicrobial susceptibility of Helicobacter pylori strains in vitro, of which the $\mathrm{MIC}_{90}$ is $1.30 \mathrm{mg} / \mathrm{mL}$ (Wu et al., 2008). Furthermore, it was found that baicalin has antiviral efficacy (Huang et al., 2017).

Through incubation of baicalin at the sub-MIC for a short period, compared with the control group, the concentration of AKP increased from 1.246 to 2.377 $\mathrm{U} / 100 \mathrm{~mL}$ in the experimental group. Alkaline phosphatase, a kind of enzyme located between the bacterial membrane and the rest of the bacterial wall, cannot be detected out of the bacteria cell wall normally.

Table 2. Numbers of drug-resistant Escherichia coli isolates before and after baicalin incubation ${ }^{1}$

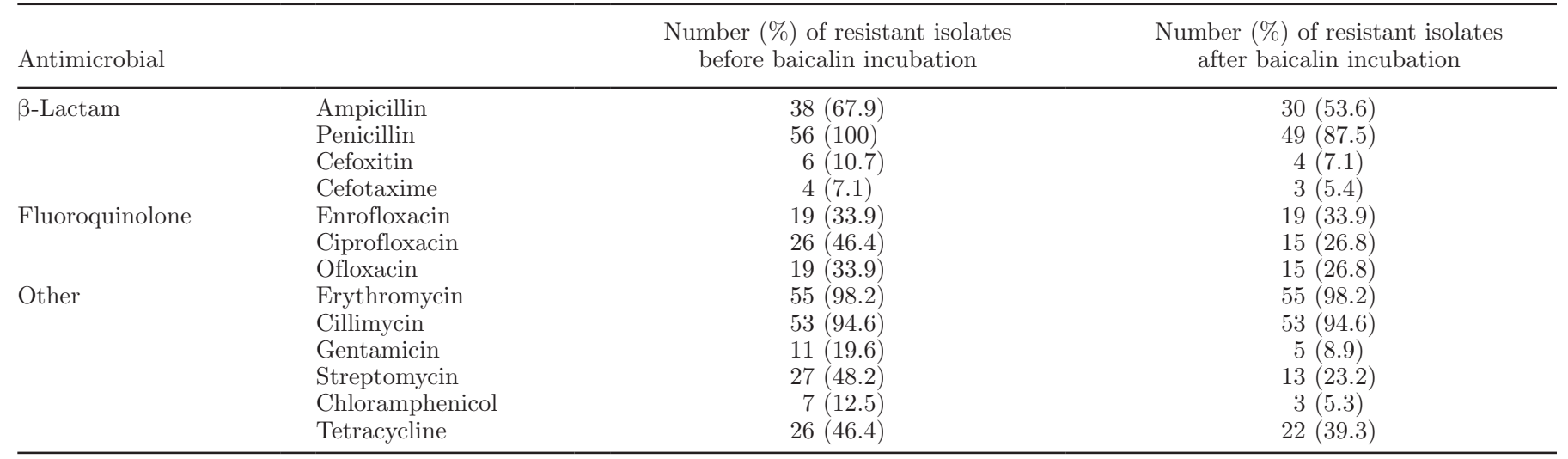

${ }^{1}$ Isolates were classified as either susceptible or resistant according to the interpretive criteria recommended by the Clinical and Laboratory Standards Institute (CLSI, M100-S25; ampicillin, penicillin, cefotaxime, cefoxitin, ciprofloxacin, ofloxacin, erythromycin, cillimycin, and streptomycin), and veterinary CLSI (gentamicin, enrofloxacin, tetracycline, and chloramphenicol). 


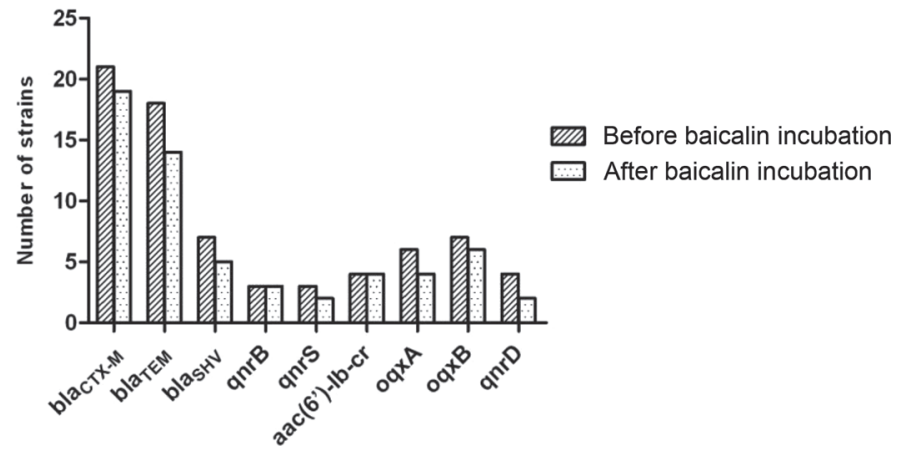

Figure 3. Changes of drug resistance genes before and after baicalin incubation. The concentration of baicalin was $2 \mathrm{mg} / \mathrm{mL}$, and the concentration of Escherichia coli was $1 \times 10^{4} \mathrm{cfu} / \mathrm{mL}$ with a period of $8 \mathrm{~h}$ of incubation.

However, bacteria cell wall damage allows access of AKP out of the bacteria cell wall (Cox et al., 2001), and this hypothesis was supplemented by evidence of the bacteria cell wall permeability test in this study. It was suggested that the increase of AKP out of bacteria cell wall are indications of permeability of the bacteria cell wall (Hara and Yamakawa, 1995). The scanning electron microscopy study showed that the surface of $E$. coli was concave and shriveled following incubation with baicalin. These indicated that the structural integrity and stability of the bacterial cell wall as a permeability barrier were changed under the effect of baicalin. It is reported that baicalin showed inhibitory effects on various gram-negative bacteria in vitro, such as Pseudomonas aeruginosa (Luo et al., 2017) and $H$. pylori (Wu et al., 2008).

In the susceptibility test of the $E$. coli isolates, susceptibility of the isolates to the certain antimicrobial agents showed a tendency to improve compared with the pre-incubation isolates. Further detections that focused on the ESBL and PMQR drug resistance genes, found that baicalin affected the plasmid-carrying resistance genes. Interestingly, one or more resistance genes of some strains could not be detected following treatment with baicalin. Compared with isolates before baicalin treatment, drug resistance genes of $12(30 \%$, 12/40) strains changed. However, due to the limited samples and current stage of our research, there were no regular or certain findings. Baicalin can significantly decrease the MIC of amoxicillin and tetracycline against some $H$. pylori strains, possibly by mechanisms associated with decreasing hefA mRNA expression by report (Huang et al., 2015). In our present study, baicalin had the similar effects on the MIC of antimicrobial agents and ESBL and PMQR genes. Also, studies performed with resistance $E$. coli isolates from cows with clinical mastitis revealed a high prevalence of strains carrying

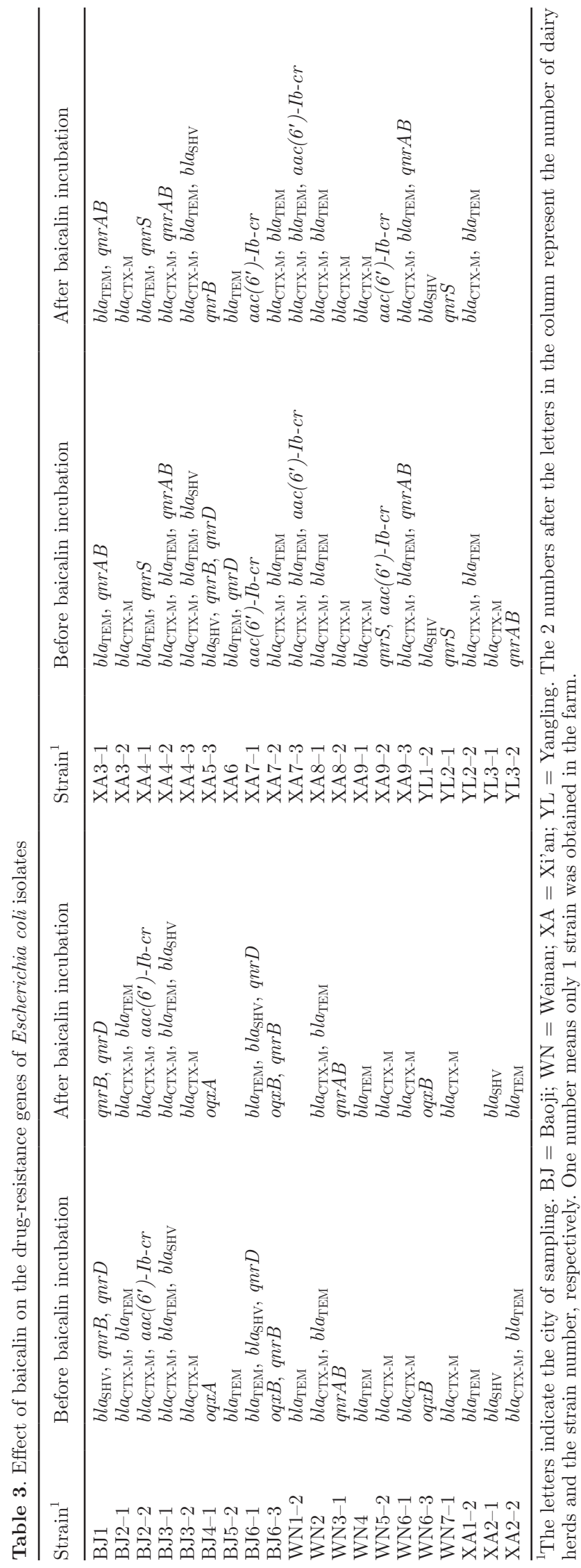


either resistance genes or plasmid-mediated related resistance genes (Suojala et al., 2011). In the case of ESBL and PMQR, the drug resistance was stronger and more prevalent in the presence of resistance genes that could conjugal transfer. (Veldman et al., 2011; Liu et al., 2014). Therefore, our studies may be helpful to the clinical application of antimicrobial agents and treatment of diseases.

Multi-drug resistance inhibitors, which were studied for inhibiting drug transport protein activity of strains in recent years, could prevent drug efflux and recover intake of drugs in bacteria, thus eliminating multi-drug resistance (Wang et al., 2008). In accordance with an earlier study, $S$. baicalensis could eliminate the resistance plasmid (which produced $\beta$-lactamase) of Staphylococcus aureus (Chen, 2010). Furthermore, some studies reported that Shuanghuanglian could inhibit the activity of $\beta$-lactamases (He et al., 2012; Lei, 2014). In our study, effects of baicalin on the drug-resistance genes of $E$. coli isolates were observable. However, the elimination mechanism was unknown.

Traditional Chinese medicine is commonly used by people in China mainly as disease treatment and a supplement to mainstream health care. There is active interest in searching for new therapeutic approaches to deal with pathogenic bacteria. In particular, alternative modes of action against drug resistance bacteria have received special attention. In the present investigation, $S$. baicalensis inhibited E. coli isolates in vitro and reduced antimicrobial resistance of the isolated bacteria. Baicalin, a rich source to combat pathogenic bacteria and reduce development of antimicrobial resistance in the dairy industry, was shown to be present in traditional Chinese medicinal herbs.

\section{ACKNOWLEDGMENTS}

This work was supported by the Key Science and Technology Program of Shaanxi Province, China (grant no. 2014K02-05-01).

\section{REFERENCES}

Ali, T., S. Ur Rahman, L. Zhang, M. Shahid, S. Zhang, G. Liu, J. Gao, and B. Han. 2016. ESBL-producing Escherichia coli from cows suffering mastitis in China contain clinical class 1 integrons with CTX-M linked to ISCR1. Front. Microbiol. 7:1931.

Bandyopadhyay, S., D. Sasmal, M. K. Ghosh, M. Bora, and M. Bhattacharyya. 2008. Antibacterial efficacy of neem (Azadirachta indica) against Morexella bovis and Neisseria. Indian J. Anim. Sci. 78:1105-1107.

Barnes-Pallesen, F. D., P. Blackmer, A. Britten, R. B. Bushnell, D. M. Van Damme, and F. Welcome. 1987. Laboratory and Field Handbook on Bovine Mastitis. National Mastitis Council Inc., Arlington, VA.
Chan, S. W., S. Li, C. Y. Kwok, I. F. F. Benzie, Y. T. Szeto, D. J. Guo, X. P. He, and P. H. F. Yu. 2008. Antioxidant activity of Chinese medicinal herbs. Pharm. Biol. 46:587-595.

Chen, S. B. 2010. Elimination effect of three kinds of traditional Chinese medicine (TCM) on R plasmid of beta-lactamase Staphylococcus aureus. Anim. Husbandry Vet. Med. 42:81-83.

Cox, S. D., C. M. Mann, J. L. Markham, J. E. Gustafson, J. R. Warmington, and S. G. Wyllie. 2001. Determining the antimicrobial actions of tea tree oil. Molecules 6:87-91.

Dahmen, S., V. Métayer, E. Gay, J. Y. Madec, and M. Haenni. 2013. Characterization of extended-spectrum beta-lactamase (ESBL)carrying plasmids and clones of Enterobacteriaceae causing cattle mastitis in France. Vet. Microbiol. 162:793-799.

Dei-Tutuwa, D., P. Amuna, and M. A. Rahman. 2014. Rapid detection of microbial contamination in Ghanaian herbal medicines by PCR analysis. Ghana Med. J. 48:106-111.

Ganderton, L., J. Chawla, C. Winters, J. Wimpenny, and D. Stickler. 1992. Scanning electron microscopy of bacterial biofilms on indwelling bladder catheters. Eur. J. Clin. Microbiol. Infect. Dis. 11:789-796.

Halasa, T., K. Huijps, O. Østerås, and H. Hogeveen. 2007. Economic effects of bovine mastitis and mastitis management: A review. Vet. Q. 29:18-31.

Hara, S., and M. Yamakawa. 1995. Moricin, a novel type of antibacterial peptide isolated from the silkworm, Bombyx mori. J. Biol. Chem. 270:29923-29927.

He, M., Z. R. Wu, Y. Li, Y. Cao, Q. C. Yao, Y. S. Zhang, S. Y. Hao, and S. Guan. 2012. Influences of Shuanghuanglian injectable powder and Qingkailing injection on $\mathrm{R}$ plasmids and $\beta$-lactamase of drug-resistant Escherichia coli. J. Beijing University Traditional Chinese Med. 35:105-108.

Heikkilä, A. M., J. I. Nousiainen, and S. Pyörälä. 2012. Costs of clinical mastitis with special reference to premature culling. J. Dairy Sci. 95:139-150.

Hillerton, J. E., A. J. Bramley, R. T. Staker, and C. H. McKinnon. 1995. Patterns of intramammary infection and clinical mastitis over a 5 year period in a closely monitored herd applying mastitis control measures. J. Dairy Res. 62:39-50.

Hogan, J. S., R. N. Gonzales, R. J. Harmon, S. C. Nickerson, S. P. Oliver, J. W. Pankey, and K. L. Smith. 1999. Laboratory Handbook on Bovine Mastitis. National Mastitis Council, Madison, WI.

Huang, H., W. Zhou, H. Zhu, P. Zhou, and X. Shi. 2017. Baicalin benefits the anti-HBV therapy via inhibiting HBV viral RNAs. Toxicol. Appl. Pharmacol. 323:36-43.

Huang, K. C. 1999. Antibacterial, antiviral, and antifungal herbs. Pages 385-386 in The Pharmacology of Chinese Herbs. 3. CRC Press, Boca Raton, FL.

Huang, R. L., C. C. Chen, H. L. Huang, C. G. Chang, C. F. Chen, and C. Chang. 2000. Anti-hepatitis B virus effects of wogonin isolated from Scutellaria baicalensis. Planta Med. 66:694-698.

Huang, W. H., A. R. Lee, and C. H. Yang. 2006. Antioxidative and antiinflammatory activities of polyhydroxyflavonoids of Scutellaria baicalensis Georgi. Biosci. Biotechnol. Biochem. 70:2371-2380.

Huang, Y. Q., G. R. Huang, M. H. Wu, H. Y. Tang, Z. S. Huang, X. H. Zhou, W. Q. Yu, J. W. Su, X. Q. Mo, B. P. Chen, L. J. Zhao, X. F. Huang, H. Y. Wei, and L. D. Wei. 2015. Inhibitory effects of emodin, baicalin, schizandrin and berberine on hefA gene: Treatment of Helicobacter pylori-induced multidrug resistance. World J. Gastroenterol. 21:4225-4231.

Lei, Y. 2014. Resistant Escherichia coli plasmid elimination and beta lactamase activity inhibition by Shuanghuanglian and Qingkailing injection. Chinese Medicine Modern Distance Education of China 20:157-158.

Levison, L. J., E. K. Miller-Cushon, A. L. Tucker, R. Bergeron, K. E. Leslie, H. W. Barkema, and T. J. DeVries. 2016. Incidence rate of pathogen-specific clinical mastitis on conventional and organic Canadian dairy farms. J. Dairy Sci. 99:1341-1350.

Li, H. B., and F. Chen. 2005. Isolation and purification of baicalein, wogonin and oroxylin A from the medicinal plant Scutellaria baicalensis by high-speed counter-current chromatography. J. Chromatogr. A 1074:107-110. 
Lindeman, C. J., E. Portis, L. Johansen, L. M. Mullins, and G. A. Stoltman. 2013. Susceptibility to antimicrobial agents among bovine mastitis pathogens isolated from North American dairy cattle, 2002-2010. J. Vet. Diagn. Invest. 25:581-591.

Liu, Y. X., G. Liu, W. J. Liu, Y. Liu, T. Ali, W. Chen, J. H. Yin, and B. Han. 2014. Phylogenetic group, virulence factors and antimicrobial resistance of Escherichia coli associated with bovine mastitis. Res. Microbiol. 165:273-277.

Luo, J., B. Dong, K. Wang, S. Cai, T. Liu, X. Cheng, D. Lei, Y. Chen, Y. Li, J. Kong, and Y. Chen. 2017. Baicalin inhibits biofilm formation, attenuates the quorum sensing-controlled virulence and enhances Pseudomonas aeruginosa clearance in a mouse peritoneal implant infection model. PLoS One 12:e0176883.

Metzger, S. A., and J. S. Hogan. 2013. Short communication: Antimicrobial susceptibility and frequency of resistance genes in Escherichia coli isolated from bovine mastitis. J. Dairy Sci. 96:30443049.

Neave, F. K., F. H. Dodd, R. G. Kingwill, and D. R. Westgarth. 1969. Control of mastitis in the dairy herd by hygiene and management. J. Dairy Sci. 52:696-707.

Olde Riekerink, R. G., H. W. Barkema, D. F. Kelton, and D. T. Scholl. 2008. Incidence rate of clinical mastitis on Canadian dairy farms. J. Dairy Sci. 91:1366-1377.

Olde Riekerink, R. G. M., H. W. Barkema, D. T. Scholl, D. E. Poolea, and D. F. Keltond. 2010. Management practices associated with the bulk-milk prevalence of Staphylococcus aureus in Canadian dairy farms. Prev. Vet. Med. 97:20-28.

Rajala-Schultz, P. J., K. L. Smith, J. S. Hogan, and B. C. Love. 2004. Antimicrobial susceptibility of mastitis pathogens from first lactation and older cows. Vet. Microbiol. 102:33-42.

Rao, L., L. Lv, Z. Zeng, S. Chen, D. He, X. Chen, C. Wu, Y. Wang, T. Yang, P. Wu, Y. Liu, and J. H. Liu. 2014. Increasing prevalence of extended-spectrum cephalosporin-resistant Escherichia coli in food animals and the diversity of CTX-M genotypes during 2003-2012. Vet. Microbiol. 172:534-541.

Saini, V., J. T. McClure, D. Léger, G. P. Keefe, D. T. Scholl, D. W Morck, and H. W. Barkema. 2012. Antimicrobial resistance profiles of common mastitis pathogens on Canadian dairy farms. J. Dairy Sci. 95:4319-4332.

Seni, J., L. Falgenhauer, N. Simeo, M. M. Mirambo, C. Imirzalioglu, M. Matee, M. Rweyemamu, T. Chakraborty, and S. E. Mshana. 2016. Multiple ESBL-producing Escherichia coli sequence types carrying quinolone and aminoglycoside resistance genes circulating in companion and domestic farm animals in Mwanza, Tanzania, harbor commonly occurring plasmids. Front. Microbiol. 7:142.

Steeneveld, W., T. van Werven, H. W. Barkema, and H. Hogeveen. 2011. Cow-specific treatment of clinical mastitis: an economic approach. J. Dairy Sci. 94:174-188.
Suojala, L., T. Pohjanvirta, H. Simojoki, A. L. Myllyniemi, A. Pitkala, S. Pelkonen, and S. Pyorala. 2011. Phylogeny, virulence factors and antimicrobial susceptibility of Escherichia coli isolated in clinical bovine mastitis. Vet. Microbiol. 147:383-388.

Veldman, K., L. M. Cavaco, D. Mevius, A. Battisti, A. Franco, N. Botteldoorn, M. Bruneau, A. Perrin-Guyomard, T. Cerny, C. De Frutos Escobar, B. Guerra, A. Schroeter, M. Gutierrez, K. Hopkins, A. L. Myllyniemi, M. Sunde, D. Wasyl, and F. M. Aarestrup. 2011. International collaborative study on the occurrence of plasmid-mediated quinolone resistance in Salmonella enterica and Escherichia coli isolated from animals, humans, food and the environment in 13 European countries. J. Antimicrob. Chemother. 66:1278-1286.

Wang, B. T., J. Xiao, Y. F. Huang, S. Q. Ren, and L. Li. 2013. Prevalence of ESBLs and PMQR genes in pathogenic Escherichia coli isolated from animals in Hefei district. Chin. J. Vet. Sci. 33:581-585.

Wang, S. L., L. Yang, Z. L. Zeng, Y. J. Luo, and Z. Q. Wen. 2008. Research progress of the eliminating effects of Chinese herbal medicine on drug resistance of pathogenic Escherichia coli. China Anim. Husbandry Vet. Med. 35:79-81.

Wu, J., D. Hu, and K. X. Wang. 2008. Study of Scutellaria baicalensis and Baicalin against antimicrobial susceptibility of Helicobacter pylori strains in vitro. Zhong Yao Cai 31:707-710.

Wu, Z. B. 2011. Pharmacological mechanism of heat-clearing effects of baicalin. Anmo yu Kangfu Yixue 56:76-77.

Xu, G., W. An, H. Wang, and X. Zhang. 2015. Prevalence and characteristics of extended-spectrum beta-lactamase genes in Escherichia coli isolated from piglets with post-weaning diarrhea in Heilongjiang province, China. Front. Microbiol. 6:1103.

Yap, P. S., T. Krishnan, K. G. Chan, and S. H. Lim. 2015. Antibacterial mode of action of Cinnamomum verum bark essential oil, alone and in combination with piperacillin, against a multidrug-resistant Escherichia coli strain. J. Microbiol. Biotechnol. 25:1299-1306.

Zadoks, R. N., H. G. Allore, T. J. Hagenaars, H. W. Barkema, and Y. H. Schukken. 2002. A mathematical model of Staphylococcus aureus control in dairy herds. Epidemiol. Infect. 129:397-416.

Zhou, Q., X. Han, X. M. Han, C. J. Yan, B. Y. Bai, W. L. Wang, and W. Zhao. 2016. Optimization of ursolic acid extraction from fructus mume and evaluation of its antibacterial activity against Escherichia coli. Food Sci. 37:67-73.

Zhu, Z. B., B. Sun, Y. D. Cui, F. Z. Pu, and Z. H. Liu. 2007. Research of four main dairy cow mastitis pathogen PCR testing method. Chin. J. Vet. Med. 43:24-27.

Zhuang, N., X. Y. Chen, L. Yue, X. P. Liao, and Y. H. Liu. 2012. Detection of PMQR gene in Escherichia coli isolated from animals. Zhongguo Nong Ye Ke Xue 45:2052-2057. 